\title{
Temple versus Household in Luke-Acts: A contrast in social institutions
}

\author{
J H Elliott \\ University of San Francisco \\ Visiting Professor, Faculty of Theology (Sec A) \\ University of Pretoria
}

\begin{abstract}
Temple versus Household in Luke-Acts: A contrast in social institutions

This social-scientific study of Luke-Acts advances the thesis that in the Lucan economy of salvation, the Temple and the Household represent opposed types of social institutions and economic relations, only one of which, the Household, is capable of embodying socially, symbolically and ideologically the structures, values and goals of an inclusive gospel of universal salvation.
\end{abstract}

\section{INTRODUCTION}

One of the most remarkable characteristics of Luke-Acts is the elaborate historical, geographical, and social concretization it gives to the good news concerning Jesus as savior of the lost and the lowly, the emergent church, and the saving acts of God in human history. More detail on the persons, groups, institutions, places, dates, and events surrounding Jesus and the early Christian movement is contained here than in any other writing of the New Testament. The function of this detail, however, is not simply to provide a 'realistic' background to an essentially independent message, but rather to give that message concrete content and shape in space and time and human interaction. For Luke writes both as historiographer and theologian. His theological aim is to convince his Christian audience of the certainty of the things

- Prof John H Elliott, Professor of Theology and Religious Studies at the University of San Francisco, visited South Africa during June and July 1990 as HSRC Research Fellow of Prof A Gan Aarde of the University of Pretoria. His contribution 'Temple versus Household in Luke-Acts: A contrast in social institutions' will be published in Neyrey J H (ed) 1991, The world of Luke-acts: $A$ handbook of social science models for biblical interpretation. Peabody, MA: Hendrickson Publishers. 
they have been taught ( $\mathrm{Lk} 1: 1-4)$ so as to strengthen faith and commitment. His method for doing so is that of a historian. 'The things that have been accomplished among us' are given historical, social and geographical profile because for Luke the theologian God saves in and through human history and for Luke the historian the ultimate arbiter of truth is the historical and social record.

Among the means by which Luke has chosen to concretize the message and meaning of the good news is his depiction of two basic institutions of Judaism and early Christianity; namely, the Jerusalem Temple and the private Household (olkos, olkía). Quantitatively, the Lucan references to these institutions outnumber those of any other New Testament writing. Qualitatively, as the use of common and special tradition, structural arrangement, and coordination of themes demonstrate, Temple and Household constitute key elements in Luke's gospel of the reign of God in human history. Although this focus of Luke's work is generally recognized (Baltzer 1965; Bachmann 1980; Weinert 1981, 1982; Cassidy \& Scharper 1983; Richard 1983; Casalengo 1984; Koenig 1985; Esler 1987), far less attention has been given to what appears to be a deliberate contrast drawn between Temple and Household and the social and ideological ramifications of this contrast in the narrative of Luke-Acts.

The term 'institution', of course, is not part of Luke's vocabulary or even of his thought-world. He, like his ancient contemporaries, spoke not of schematized wholes but rather of related parts: a holy place of prayer and sacrifice, priests, rulers, law and lawyers, purity observance on the one hand; and homes, family members, servants, friends, meals, hospitality and domestic life on the other. Luke the first-century historiographer, in other words, tells his story from a 'native's' point of view or what is termed in anthropology the 'emic' perspective. On the other hand, from an analytical, social scientific point of view, or 'etic' perspective, what Luke portrays are aspects of two major institutions of first-century Palestinian society, the Jerusalem Temple and the private Household. Institutions comprise social associations or processes which are highly organized, systematized in terms of roles, relationships, and responsibilities, and stable over time. As 'institutions' in the formal sociological sense, the Temple and the Household entail not simply different spaces for worship or residence, respectively, but differently organized sectors and systems of social life. Therefore our investigation of the main Lucan material pertaining to the institutions of Temple and Household will include not

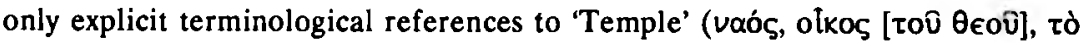
lepóv) and 'Household' (ołkos, olki $\alpha$ ) but also their semantic fields and social domains; that is all the connected groups, roles, structures, and patterns of behavior, norms, values and cultural symbols; and economic, political, and ideological features 
which comprise their respective institutional character. Such an inclusive body of data will provide a comprehensive basis for relating and analyzing the distinctive features of each institution and the implications of their contrast in Luke-Acts.

The thesis advanced in this study is that in the Lucan economy of salvation, the Temple system and the Household represent opposed types of social institutions, only one of which, the Household, is capable of embodying socially, symbolically and ideologically the structures, values and goals of an inclusive gospel of universal salvation. By combining an analysis of the Lucan Temple/Household contrast with aspects of previous exegetical research and filtering this data through the lens of an anthropological model of alternate types of ancient social relations, I intend to show its general function in the narrative: how this contrast coheres with dominant Lucan themes, how it advances Luke's conception of the gospel and depiction of Christian community, and why it made compelling sense in Luke's social context.

This study is a follow-up on some brief comments I made concerning the significance of the Household in Luke-Acts in my earlier work, $A$ home for the homeless. There, in a sketch of 'the significance and function of the okxos in the Old and New Testaments' (Elliott 1981:182-200), I observed that:

In Luke-Acts the Household is prominently contrasted to the temple, the bankrupt seat of Jewish power and piety, and to the city, the area of 'Caesar's's network' and locus of social control....For the Christians [of Luke-Acts] the oikos constitutes not simply an additional form of social identity and religious allegiance alongside others such as the temple, the synagogue, or the city. The Christian olkos is rather a decisive alternative according to Luke. Membership in the former involves constant conflict with and critique of the latter.

(Elliott 1981:193-194)

As an expansion on these brief observations I shall now turn to an examination of the complete Lucan text narrative and the role of the Temple/Household contrast in particular. 


\section{TEMPLE AND HOUSEHOLD: ASPECTS OF CONTRAST}

\subsection{Temple and Household in Luke 18:9-14}

The contrast between Temple and Household in the critical parable of the Pharisee and the Tax Collector (Lk 18:9-14) may serve as our point of departure. In this parable, intended by Luke as an indictment of those persuaded of their righteousness and despising of others (18:9), three contrasts are drawn between (1) the actors and their actions, (2) the content of their prayers, and (3) locale. The actors are key figures of the Lucan narrative, representing throughout the Gospel those at the center and those on the periphery of Judaism's social and religious life. The Pharisee, certain of his favor with God and his superiority over others like the tax collector, plies God in prayer with his punctilious piety (vv 11-12). By contrast, the self-deprecating tax collector throws himself as a sinner fully on God's mercy (v 13). The upshot of the story ( $v 14$ ) involves not only a contrast in Jesus' verdict between the tax collector who was justified by God and the Pharisee who was not, but also a shift in locale. 'This man went down to his house (olkos) justified rather than the

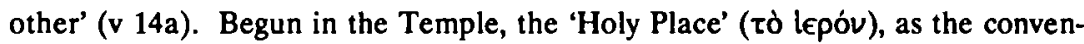
tional place for demarcating social and religious differences, the story concludes with the olkos as the locus of the justified.

In the parable itself, this contrast in locales at first glance appears of minor importance. The framing function of lepóv ('holy place', 'Temple') and olkos, however, gives cause to pause. One commentator on this passage, Henry Mottu (1974:199), in fact, maintains that 'these descriptions of the "where" of human living, pointing to two different loci and thus to a spatial contradiction between "temple" and "house", lepóv and olkos, seem to me to represent the primary dialectical contradiction in the story.'

For Mottu, Temple and olkos denote contrasting social spaces and contrasting forms of social life; the former, an alienating form of collective, institutional life, the latter, a creative form of integrative group life. He goes on to observe that

As long as the two antagonists look at the temple as their locus of reference, they stay in an alienated organization of space that makes human reality inhuman. The skopos (goal) of the story seems $\boldsymbol{\theta}_{0}$ me to be located in an invitation to change the rules of the common spatial game, to transform collectives into groups and to give a 'house' to displaced persons. No conversion, no morals, no opposition of two 'characters' is the skopos; but a shift of space, a structural change, a transformation of where people live is what we are invited to accom- 
plish. The opposition between the Pharisee and the tax collector is only the secondary aspect of the dominant contradiction which is the spatial contradiction between temple and house, collective and group, alienated and human space.

(Mottu 1974:201-202)

Mottu expands on these observations from a phenomenological point of view informed by the work of Jean Paul Sartre. He is expressly not concerned with correlating this text with the Lucan project as a whole (Mottu 1974:197). Consequently, his thoroughly negative reading of the significance of Temple in this parable lacks balance with a positive portrayal of the Temple found earlier in Luke (chs 1-2) and fails to capture 'Luke's ambivalent attitude to the Temple' (Esler 1987:133-135). Nevertheless, the dramatic contrast he notes between Temple and Household in this parable of special Lucan material appears to me worthy of further analysis at the hand of Luke's entire composition. Is more implied here than first meets the eye? Are Temple and Household contrasted elsewhere in the Lucan narrative? Does it appear that this contrast involves opposing forms of social organization, relations, and values? Do Temple and oikos and their respective networks of relations depict in Luke-Acts contrasted styles of piety and behavior? A sustained examination of Luke-Acts indicates that such, indeed, appears to be the case.

\subsection{Temple and Household in the general structure of Luke-Acts}

That the contrast between Temple and Household in Luke 18:9-14 is neither coincidental nor singular is indicated, first, by two structural features of Luke-Acts. As has long been recognized, it is with scenes in the Temple that the first half of the Lucan two-volume work begins and ends. Commencing with the story of Zechariah's priestly service in the Temple and the angelic announcement of his son's birth (1:5-23), the Gospel concludes with the disciples' departure from Bethany and the parting of the risen Lord and their return to Jerusalem where they were 'continually in the Temple blessing God' (24:50-53). Temple scenes thus provide a grand framework or inclusio for the first half of Luke-Acts. It is likewise the case, however, that as Temple scenes frame the first half of the Luke-Acts, scenes in the Household frame the second half. Commencing with the gathering of the faithful in the house with the upper room (Ac 1:12-14), following the Lord's ascension (1:1-11), Acts concludes with Paul's house confinement in Rome and his unhindered proclamation of the gospel (28:30-31). Once again, but on a grander scale, the scene shifts 
from Temple to Household.

A second structural indication of this contrast is evident in the early narrative of Acts. Within the first eight chapters the scene shifts with regularity between the oixos where the believers assemble, pray, receive the Spirit, break bread and generously share all things in common and the Temple as the center of political and religious control, a place for seeking alms, and the scene and object of conflict (arrest and imprisonment, critique of Temple rulers, mob violence, beating, and death):

House

$1: 13-2: 45$

4:23-5:11

$6: 1-7$

$8: 4 \mathrm{ff}$.
Temple

$3: 1-4: 22$

$5: 12-40$

\section{6:8-8:3}

This pattern of alternating scenes clearly demarcates two areas of action and two differentiated communities, their variant forms of social and economic organization, and their ultimately contrasting loyalties. The one represents Temple rule, norms and allegiance; the other, a new community of witnesses to the resurrected Christ based in the Household, inspired by the divine Spirit and loyal to the God who does not dwell in man-made houses or temples (Casalengo 1984:146-147, 196-197).

In these early chapters of Acts, the Temple is both the scene and the subject of conflict. An instance of almsseeking and healing at the Temple (3:1-4:22) becomes an occasion for distinguishing between those who take and those who give life, those who killed the 'Author of life' (3:15) and those who heal in his name (3:16). Temple authorities (priests, Temple captain, and Sadducees, 4:1; rulers, elders, scribes, high priests and family, 4:5-6, 5:17; Sanhedrin, 4:5-6, 15; 5:21, 27; 6:12-15) in their jealousy (5:17), opposition to the apostles' teaching (4:2; 5:18, 27-28; 6:57), and their actions of arrest, imprisonment, beating, and killing (4:3; 5:18, 40; 6:57-58), defend monopolistic Temple interests by seeking to suppress the joyous community which gives health (3:1-10; 5:16), celebrates the covenant of Abraham given through God's resurrected servant to 'all the families of the earth' (3:25-26), praises God (4:24-30), and is filled with the Spirit $(4: 8 ; 5: 21 ; 7: 55)$.

For Stephen, charged with speaking 'words against this holy place and the law' (6:13-14), death is the result of his verdict on the Temple as the house of Solomon 
but not the dwelling place of God and on its functionaries as the murderers of the Righteous One (7:46-58). In the only other set of references to the Jerusalem Temple in Acts, Paul's Temple visit and the plot against his life (21:26-36) and Paul's defenses (in chs 22-26), the Temple is portrayed similarly as the scene of assassination conspiracy, conflict over purity, and political collusion (Temple authorities, Herodians, and Romans). After Stephen's death, the persecution of the Jerusalem church, and its dispersion (8:1b ff), it is the Household, on the other hand, which becomes the basis of the church's life and the focus of its mission.

Throughout Luke-Acts a transition thus becomes apparent in regard to Temple and Household. In Luke, the Jerusalem Temple marks the structural frame (chs 12, 24:52-53) and the focus (9:51: 'he set his face to go to Jerusalem'; of 13:22; 17:11; $18: 31 ; 19: 28)$ of Jesus' life's journey, with Household visits and instruction (7:1-10, $36-50 ; 8: 40-56 ; 10: 38-42 ; 12: 13-53 ; 13: 18-30 ; 14: 1-24 ; 16: 1-17: 10 ; 18: 18-34 ; 19: 1-10$ ) frequently providing the positive contrast to the negative climax of confrontation and death in Jerusalem. In Acts, the Household becomes increasingly prominent as the scene and focus of the Christian movement gradually shifts from Jerusalem and the Temple to the Households of the Diaspora. At first the messianic community gathers both at the Temple and in homes $(2: 43-47 ; 5: 42)$. But the attempt at peaceful coexistence fails. Agents of the Temple become the hunters and followers of Jesus, the hunted. The episode of Stephen's speech and stoning in connection with remarks concerning the Temple forms a turning point between the earliest phase of the church's life and its connection with the Temple (chs 1-8:1a) and its fullscale mission to the Households of the Diaspora (8:1b-28:31). In the remainder of Luke's account, the Temple plays no positive role as a place of Christian assembly or symbol of Christian identity. Along with the synagogue which represents the extension of Temple authority and values, the Temple reckons only negatively as a locale of Jewish-Christian conflict over purity and its implications for the course of universal salvation. By contrast, the story of the Jesus movement concentrates positively on the olxos as the focus of the movement's recruitment, the locus of its assembly, worship, and mutual support, and the basis for the social embodiment of its evangelical message.

In sum, the juxtaposition of scenes in Acts 1-8 and the inclusive framework of Luke (Temple) compared with its counterpart in Acts (Household) suggest a purposeful contrast of locales, groups, and institutions within a historical and theological movement commencing with the Temple and concluding with the Household.

These larger patterns of contrast in the Lucan narrative appear consistent with the contrast drawn between Temple and olkos in Luke 18:9-14. The Temple and 
the Household constitute not simply different sites of activity but bases of different and conflicting groups of actors with differing and conflicting sets of interests and allegiances. From commencement to close of the Lucan narrative, moreover, it is the Household which gradually replaces the Temple as the actual sphere of God's saving presence. The Temple, at first the locale of hoped for salvation and symbol of Israel's holy union with God, eventually is unmasked as the political concentration of power opposed to God's people and the truly righteous. The Household, on the other hand, once the gathering place of the powerless and the marginalized, eventually emerges as the institution where God's spirit is truly active and where familial relations, shared resources, and communal values concretize the vision of a salvation available to all the families of the earth.

This general picture gained from initial structural observations now needs filling in with more specific detail. How are both the Temple and the Household depicted in Luke-Acts? By what terms and semantic fields ( $i$ e related terms encompassing a specific area of cultural experience; cf Nida 1975) are they identified and evaluated? What domains of social (economic, political, religious-ideological) experience do they represent? What agents, interest groups, activities, attitudes, expectations, norms, goals, and values do they embrace? What, in other words, are their specific institutional features as presented in Luke-Acts, and how does their contrast serve to concretize Luke's particular conception of the good news? A survey of the more salient features of both Temple and Household in the Lucan narrative will indicate both the major importance ascribed to each and the chief aspects of their contrast as alternative forms of social organization, identity, and commitment.

\section{THE TEMPLE IN LUKE-ACTS}

\subsection{Temple terminology, semantic field, and scenes}

In Luke-Acts three Greek expressions are used to designate the Jerusalem Temple:

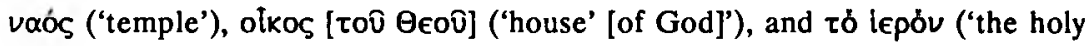
place').

* Naós ('temple') occurs four times in Luke, thrice identifying the scene of Zechariah's priestly activity $(1: 9,21,22)$, and once in a reference to the rending of the Temple curtain at Jesus' death (23:45; cf Mt 27:51; Mk 15:38). In Acts the term designates pagan 'temples' (17:24) or miniature silver replicas of the Artemis temple of Ephesus (19:24).

* Olkos ( zoט $\theta \epsilon o \bigcup$ ) as a second term for the Jerusalem Temple appears possibly four times in Luke and once in Acts, all in contexts of conflict or censure. In 
conflict with the Pharisees over the sanctity of the sabbath rest, Jesus defends his disciples' plucking and eating grain with an appeal to David's entering the house of God and eating the bread of the Presence, a privilege reserved only to priests (Lk 6:4). In censure of the lawyers (and Pharisees) for burdening people with the law but not aiding their entrance into the Kingdom (11:45-52) and for consenting with the murderous deeds of their fathers, Jesus refers to the shed blood of the prophets, including that of Zechariah who perished between the altar and the 'sanctuary' (RSV) (otkos) (11:51). In 13:35, Jesus' word of judgment, 'Behold, your house (olkos) is forsaken', is ambiguous, referring either to the Temple in particular or to Jerusalem (cf 13:34; Weinert 1982), though both are interchangeable as symbols of a condemned Israel. Finally, Jesus condemns the Temple merchants with the words: 'It is written, "My house (oikos) shall be a house (oikos) of prayer"; but you have made it a den of robbers' (19:45-46). In Acts, Stephen, affirming that God 'does not dwell in houses made with hands' (Isa 66:1-2), contests God's dwelling in the house (olkos) built by Solomon (7:47-50).

- The substantive tò lepóv, however, used fourteen times in Luke and twentyfour times in Acts (more than in the rest of the New Testament writings combined), is the predominant Lucan term for designating the Jerusalem Temple, including its buildings, precincts and courts, as 'the sanctuary' or 'holy place'. For Judaism, the Temple as Israel's central holy place represented the chief visible symbol of its identity as God's holy people. The holiness of its space, its personnel (priests [lepeî́] = 'holy functionaries'; chief priests [dpxlepeic]; Levites), its sacrifices, and of the laws of holiness it enforced symbolized a holy people's union with the Holy One of Israel. This link between the holy place and the holy people and their demarcation from all that was unholy was derived from the Torah and elaborated, maintained, and legitimated in an ideology and system of holiness which defined Jewish identity and regulated all aspects of Jewish life. Where Temple and Torah are involved in Luke's narrative, therefore, crucial issues regarding norms of holy behavior and social interaction and the boundaries of God's holy people are at stake.

In Luke, the Temple as holy place is first the scene of Jesus' presentation, Mary's purification (in accord with Torah), Simeon's and Anna's blessing of the child, and, years later, of Jesus' discussion with teachers after the occasion of a Passover pilgrimage (2:22-51). Initially, the Temple is the place where Jesus' fidelity to the Law, his role as agent of divine salvation, redemption and mercy, and his wisdom are manifested. With the commencement of his public ministry, however, the 
Temple scenes in Luke-Acts take on a more ominous hue. In Luke's redaction of the temptation account, it is Jesus' confrontation with devil at the Temple which forms the climactic conclusion of the episode (4:9-13; cf Mt 4:5-7). In the parable of the Pharisee and the tax collector (18:9-14), the holy place as a scene of alienation between the holy Pharisee and the unholy tax collector is contrasted to the olkos of the justified sinner. Upon his arrival in Jerusalem, that ominous moment long anticipated in the narrative $(9: 30-31,51 ; 13: 22 ; 17: 11 ; 18: 31-34)$, it is the holy place and the holy city which form the combined object of Jesus' passionate condemnation (19:41-44; 45:46; cf 13:33-35). Thereafter, the Temple reckons primarily as the arena of Jesus' conflict with the Temple (chief priests; Sadducees) and related legal authorities (chief priests, scribes, elders; i e Sanhedrin) and their conspiracy with the Roman governor to take his life (19:45-47; 20:1-22:6; 22:47-23:25).

At the conclusion of Luke (24:52-53), as at the outset of Acts $(2: 46 ; 3: 1 ; 5: 12,20$, 42), the disciples worship or teach in the Temple. But the holy place continues as an arena of conflict (Ac 3:1-4:22; 5:12-42). For Paul, as for Jesus, despite his conformity to the law (Ac 21:17-26), the holy place and the holy city remain the locale of hostility, political collusion, and conspiracy against innocent life (21:27-26:32).

This review of explicit Temple references also exposes elements of the semantic field associated with Temple in Luke-Acts. This wider semantic field, a set of terms related to a specific area of cultural life (Nida 1975:22), in this case the social domain of the Jerusalem Temple, provides a broader picture of the features associated with the Temple in the Lucan narrative. Sacrifice, prayer, praise, revelation, hope of salvation, tithing and legal observance are all activities associated with the Temple. But so is priestly political power, economic disparities, scribal arrogance and exploitation of the poor, conflict of Jesus and his followers with Temple authority, their critique of the Temple establishment, death plots and unjust executions. The Temple and Jerusalem, the Holy Place and the Holy City, constitute for Luke the dominating public center of Jewish society and that web of social relations within which the Jesus movement was born but with which it also came into irremediable conflict. The Holy Place and the holiness ideology it embodies eventually emerges in Luke-Acts as an entire system at odds with the will of God and the realization of salvation.

\subsection{The Temple network and purity system in Luke-Acts}

In Luke-Acts various interrelated groups of the Temple network are depicted as playing key roles in the opposition to Jesus and his followers: chief priests and minor clergy, scribes, elders, Sanhedrin, Sadducees and Pharisees. 
At the pinnacle of the Temple hierarchy were the chief priests (apxtepeis). Allied with the Sadducean faction (Ac 5:17), and controlled by the Roman governor, this priestly aristocracy represented the power of the Temple over all aspects of Jewish political, economic, social and cultural life. With the scribeslawyers and elders (the landed, lay aristocracy), they also constituted the Sanhedrin, the 'supreme court' of the Jews. In Luke-Acts, as in the other Gospels, it is these wielders of Judaism's unified political, economic, legal, and religious power who play the decisive role in the conflict involving the Jesus

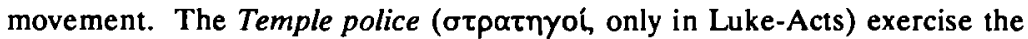
coercive power of the holy place (Lk 22:4, 52; Ac 4:1; 5:2, 24, 26). The Chief priests, together with the Scribes and Elders and in collusion with Rome (Lk 23:1-25; Ac 24-26), conspire with an agent of Satan (Judas Iscariot, Luke 22:3) to kill Jesus (Lk 9:22; 19:27; 20:1, 19;22:2, 4, 52, 66;23:10, 13;24:20) and suppress his movement (Ac 4:5, 23; 5:27; 6:12-15; 9:1, 14; 22:30-26:32).

- Scribes, though not cultic officials but rather official interpreters of the Mosaic Law (Torah), constituted a further arm of the Temple apparatus described by Luke. As noted, they held a key position in the Sanhedrin and, like the faction of the Pharisees, represented the link between Temple authority and Torah observance. In Luke's account, it is these scribal Temple and Torah authorities who embodied the injustice and oppression of the Temple as an economic institution. Like the Pharisees condemned by Jesus as 'lovers of money' (Lk 16:14) and 'extortionists' (11:42; cf also 11:37-44; 12:1; 15:1-31; 16:14-15; 18:9-14), and the Temple merchants accused of making of the house of God and prayer 'a den of thieves' (19:45-47), the scribes are censured in the Temple itself for seeking public honor in the synagogues while they secretly 'devour widows' houses' (20:47). Jesus' exposure of their machinations (cf also 20:1-26) attacks the economic as well as religious corruption of Temple politics and condemns a system organized not for prayer, justice and mercy but for self-aggrandizement and exploitation. Accordingly, in Luke-Acts, the scribes also play a major role in the plot against Jesus and his followers (Lk 11:54; 19:47; 20:19; 22:2, 66; 23:10; Ac 4:5; 6:12; 22:30-23:15).

- Other Temple personnel, ordinary priests (tepeî́: Luke 1:5; 5:14; 6:4; 10:31; 17:14; Ac 4:1; 6:7) and a Levite (Lk 10:31) represent, with the lay faction of the Pharisees, a further key aspect of the Temple system as seen in Luke-Acts. This concerns the fundamental conception of the Temple as the 'holy place' where holy priestly personnel served (e g Luke 1:8), purification was effected (Lk 2:22) 
and certified (Lk 5:14; 17:14) in accord with Torah (Lev 13-14), and all matters regarding the 'holiness' = 'cleanness' of the Jewish people were regulated. The Pharisees, enforcing Temple purity regulations still more rigorously, had extended the norms of Temple and priestly holiness to the bed and board of every observant Jewish home. In Luke-Acts this purity system symbolized by the Temple and controlled by the Temple establishment becomes a major point of controversy and contrast concerning the praxis of the Temple guardians and that of Jesus and his followers. In order to grasp the implications of this conflict over purity, it is necessary to see how Judaism's purity system functioned from a social scientific point of view.

- The Temple purity system, as Malina (1981:122-152) and Neyrey (1986:91-128; cf Neusner 1973) have shown, established and controlled the social identity, social classifications, and social boundaries of the Jewish people as the holy people of God. Israel's land and places (Mishnah Kelim 1.6-9), classes of persons (Tosephta Megillah 2.7), holy times (Mishnah Moed), and unholy physical 'uncleanness' (Mishnah Kelim 1.3) were all classified and ranked according to an elaborated map of degrees of purity or impurity. This system established the structure and social stratification of the Jewish community (Jeremias 1969:271358), the norms of public and private behavior, and the lines of demarcation between holy Israelites and all at or beyond the margins of God's holy people (i e physical or social deviants, Samaritans, and Gentiles). This organization of society along purity lines called for a careful avoidance of contact with all that was judged impure or unholy (sinners, lepers, blind, lame, menstruants, corpses, toll collectors, Samaritans, Gentiles) and proper respect for holy places (Temple, synagogue), holy persons (Temple personnel), acts of purification (hand washing before meals) and holy times (Sabbath, festivals). According to this system of economic and social stratification legimitated by purity classifications, the rich were ranked above the poor, the clergy above the laity, urban dwellers (especially in Jerusalem) above the rural peasantry (especially in distant Galilee), men above women, married above unmarried, healthy above the ill, conformists above deviants.

According to Luke, as well as the other Evangelists, it was this system of purity and the exclusivity and injustice which it fostered which Jesus challenged (Borg 1984). This challenge, so wide-reaching in its political and social ramifications, inevitably led to conflict, death, and social division. 
The picture Luke paints of Jesus' attitude toward purity norms is a complex one. On the one hand, Jesus, his family and followers respected the holiness of the Temple as a house of prayer ( $\operatorname{Lk} 19: 46$; Ac 3:1), a place of purification (Lk 2:22, $5: 14 ; 17: 14$ ) and pilgrimage (Lk $2: 41 ; 9: 51)$, the holiness of the synagogue as a place of teaching and hearing ( $L k$ 4:16-30; Ac 13:5 etc), and the holy festivals (Lk 2:41; $9: 51 ; 22: 7 \mathrm{ff}$; Ac $2: 1$ ). On the other hand, however, the ministry of Jesus and his movement also is marked by what is perceived to be a flagrant disregard of the purity norms concerning persons, behavior, times and places.

Jesus and his followers regularly associate with and frequently 'cleanse'/ 'sanctify' unholy persons:

- $\quad$ the physically unclean lepers: Luke $5: 12-15 ; 7: 22 ; 17: 11-19 ;$ cf $4: 27$; cripples: Luke 5:17-26; Acts 3:1-10; 9:32-34; menstruants: Luke 8:42-48; the blind: Luke 7:21; cf 4:18; the sick: Luke 4:38-40; Acts 5:15-16; eunuch: Acts 8:2639; the demon possessed: Luke 4:31-37; 8:26-39; Acts 16:16-18; the dead: Luke 7:11-17; 8:49-56; Acts 9:36-41; 20:9-10.

- 'sinners': Luke 5:8-10, 30; 7:34, 37-39; 15:1-2.

- $\quad$ tax/toll collectors: Luke 5:27-32; 7:29, 34; 15:1-2; 18:9-14; 19:1-10; cf 18:914.

- $\quad$ Samaritans: 9:52; 17:11-19; Acts 8; cf Luke 10:29-37.

- $\quad$ Gentiles: Luke 4:26-27; 7:1-10; 8:26; 24:27; Acts 1:8; 10:1-11:18; cf 15:6-20; 28:28.

They also disregard the purity lines drawn around holy behavior:

- by eating common food with common people (Lk 9:10-17) and specifically unclean persons: Luke 5:27-31; 7:34; 15:1-2; 19:7; Acts 10-11.

- by neglecting cleansing rituals: Luke 11:37.

- by disregarding dietary regulations: Luke 10:7-8; Acts 10-11.

- by touching unclean bodies: corpses (Lk 7:14; 8:54; Ac 9:40-41; 20:10); lepers (Lk 5:13); menstruants (Lk 8:44); and the tears, hair and lips of a sinful woman (Lk 7:38).

Holy times are also violated:

- no strict Sabbath observance (Lk 6:1-5, 6-11; 13:10-16).

- no fasting days (Lk 5:33-34; see criticism of fasting in Lk 18:12). 
Finally, holy places and personnel are criticized and disrespected:

- critical remarks against the Temple and its network: the Temple (Lk 19:4547; 21:6; Ac 6:14; 7:48-50); the chief priests, scribes, and elders (Lk 9:22; 20:9-20; 22:50-53, 67-71; Ac 4:8-12; 5:29-32; 7:51-53); priest and Levite (Lk 10:29-37); scribes (Lk 11:45-52; 15:1-32; 20:45-47); Sadducees (Ac 4:8-12, 23:6-9; cf Luke 20:27-40); Pharisees (Lk 7:36-50; 11:37-44; 12:1-3; 14:1-24; $15: 1-32 ; 16: 14-15 ; 18: 9-14$; cf 5:17-26; 6:1-5, 6-11, 39-42; 12:56, 13:10-17).

- critical remarks against the Holy City of Jerusalem: Luke 13:33-35; 19:41$44 ; 21: 20-24$.

- disregard for the limits of the Holy Land and the Holy People of Judaism: Jesus' commission of his followers to leave the Land 'for the ends of the world' (Ac 1:8) and 'to preach in his name to all nations (Gentiles)' (Lk 24:47; cf Ac 28:29).

Consequently, the incriminating charge of defilement levelled against Jesus and his company becomes a global one. Jesus is accused of 'perverting our nation' (Lk 23:2, 14); Stephen is charged with speaking 'blasphemous words against Moses and God,...this Holy Place and the Law...claiming that this Jesus of Nazareth will destroy this place and will change the customs which Moses delivered to us' (Ac 6:11-14). And Paul is denounced as "teaching men everywhere against the people and the Law and this place' and by, bringing Greeks into the Temple, 'defiling this Holy Place' (Ac 21:28).

\subsection{The Temple institution in Luke-Acts: A summary}

In the Lucan narrative the Temple gradually emerges as an institution whose managers, interests, and ideology stood diametrically opposed to the ministry and mission of Jesus and his community. Constituting with Torah and purity system the chief symbol of Jewish national identity, the Temple, for Luke, was a holy place which had lost its power to make holy, that is, to bring all who were unholy into communion with the Holy One. This center of Jewish political, economic, and social power, through its collusion with Rome and its oppression and exploitation of its own people, was once but no longer the place where the hope of the world's salvation and the universal experience of God's mercy could be realized. Temple functionaries and other agencies of the Temple apparatus appear guided by their own self-interests in preserving an exploitative regime in which the mighty remain in their seats and nothing but disdain and neglect is shown those of low degree. For all those outside the holy boundaries of Israel, the physical limits of the Holy Place and 
the social restrictions of its purity system effectively prohibited the access of all to sanctification, health, and salvation. Within the borders of Israel demarcated by the purity system, the economic power of the Temple from taxes, tithes, sacrifices and offerings was used to promote the programs of the powerful at the expense of the powerless. Priest and Levite protected their purity rather than extended mercy. Scribes devoured widow's houses, Pharisees neglected justice and mercy, chief priests and Sanhedrin conspired to condemn the critics and eradicate the agents of change. The call to repentance was met with the plot to remove. Efforts to redefine the purity which God requires and consequently the behavioral norms and social identity of God's holy people were denounced as plots to pervert the nation and its sacred customs. Reform program was countered by death plot, critique by condemnation. The presence of the Spirit eventually shifted from the Temple in Jerusalem to the Households of the Diaspora. In contrast to the Temple, the Household gradually emerged as the venue of sanctity and divine salvation.

Considering all the related aspects of the Temple as a comprehensive social institution, its political, economic, social, and cultural dimensions and its accompanying purity ideology, has provided us with a full picture of the Temple system as portrayed and evaluated by Luke. Failure to take into account this full range of data can lead only to unbalanced and inaccurate conclusions. Thus Weinert's contention (1981) that 'Luke avoids any polemic against the Temple' appears wide of the mark. Weinert isolates references to the Temple from those concerning Temple authorities (see Cassidy 1983 and Tannehill 1986:169-199) and their unjust programs, understates Jesus' and Stephen's critique of the Holy Place and its management, and ignores the negative implications of the Temple's purity system altogether. Secondly, this survey has revealed what for Luke are those key issues over which the Jesus movement and Temple establishment collided. Lastly, this analysis has highlighted salient features of a political institution, the Temple, with which another form of institution based on kinship, namely the Household, can instructively be compared.

\section{THE HOUSEHOLD IN LUKE-ACTS}

Over against the society demarcated by these bonds and boundaries of social identity and a Temple administration intent on the elimination of Temple critics and purity violators, according to Luke, stands a community in solidarity with Jesus and the righteous victims of Temple 'justice', a community organized not around the Temple but around the Household and bound by an ethos of mercy and justice and a vision of universal salvation. 
4.1 House and Household: Terminology and prominence

In Luke-Acts the 'house' (olxí) and 'Household' (olxos), comprising family and kin, personnel and property, play a prominent, if not dominant, role in the narrative. The term olki $\alpha$ appears twenty-five times in Luke and twelve times in Acts; olkos, another thirty-four times in Luke and twenty-five times in Acts. These references to domestic residences and communities are joined by numerous related terms of the

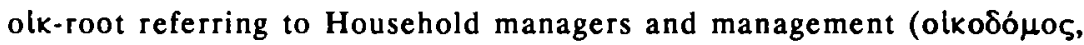

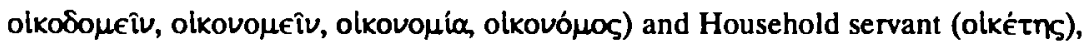

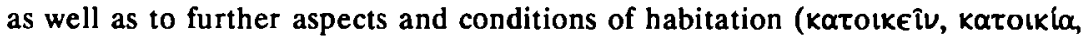

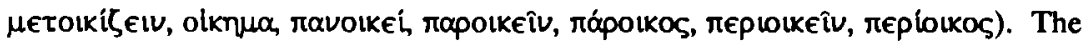
range of this terminology alone already gives a strong impression of the importance which domestic conditions and relations play in Luke's social concretization of the gospel.

More than any other writing of the New Testament, Luke-Acts makes clear the fundamental role which private houses and Households played in the geographical spread of the Jesus movement, the domestic form of organization it assumed, and the social relations and values it fostered. In contrast to the Temple, the place of hostility and the focus of critique, the oikos represents in Luke-Acts the favored setting of the teaching and healing ministry of Jesus and his followers and the typical location of the gospel's reception and the church's growth. Moreover, it is characteristic features of domestic life which serve to illustrate in the Lucan narrative notable aspects of Christian values and social relations rooted in the institution of kinship: solidarity, loyalty, trust, mutuality of obligations, generosity, sharing and the like.

\subsection{Household settings}

Houses, homes and households, first of all, provide in Luke-Acts the setting for a wide range of events in the life of Jesus and his followers:

- the proclamation of the gospel, the experience of forgiveness of sins, salvation and the presence of the Spirit: Luke 1:39-56; 5:17-26; 7:36-50; $8: 38-39,49-56 ; 9: 4 ; 10: 5-7 ; 12: 3 ; 15: 11-32 ; 18: 14 ; 19: 1-10$; Acts $2: 1-42 ; 5: 42$; $10: 1-48 ; 11: 14-15 ; 16: 25-34 ; 18: 7-8 ; 22: 16$ (cf $9: 19$ ).

- teaching: Luke 7:36-50; 10:38-42; 11:37-52; 14:1-24; 22:24-38; Acts 2:42; $5: 42 ; 18: 11 ; 20: 7-12,20 ; 28: 30-31$.

- $\quad$ healing: Luke $4: 38-41 ; 5: 18-26 ; 7: 1-10 ; 8: 4-56 ;$ Acts $9: 10-19,32-35,36-43$; 20:7-12; 28:7-10.

- $\quad$ prophecy: Acts 2:1-21; 21:8-14. 
- revelations and visions: Luke 1:26-38; 24:28-35; Acts 1:13-26; 9:10-19; 10:18, 9-23; 11:13-14; 13:2; 18:7-10.

- recognition of the resurrected Christ: Luke 24:28-32.

- redefining the family of Jesus: Luke 8:19-21.

- hospitality and lodging: Luke 19:1-10; Acts 9:10-19, 43; 10:6; 12:12$17 ; 16: 15,34 ; 17: 5 ; 18: 7 ; 21: 8,16 ;(27: 3) ; 28: 7-10,13-14$.

- hospitality of meals and dining sociality: Luke 5:29-39; 7:36-50; 10:38-42; 11:37-52; 14:1-24; cf 15:2; 22:7-38; 24:28-32, 36-49; Acts 9:19; 10:1-11:18; $16: 34$.

- worship: (prayer, praise, fasting, Passover meal, baptism, Lord's Supper): Luke 1:39-56; 22:7-38; 24:28-35; Acts 1:14; 2:46-47; 4:23-31; 9:10-19; 10:1-8; $12: 12 ; 13: 2 ; 16: 33 ; 20: 7-10$.

- sharing property and distribution of goods to the needy: Luke 19:1-10; Acts $2: 44-45 ; 4: 34-37 ; 6: 1-6 ; 9: 36-42 ; 10: 1-2$; cf 20:34-35.

\subsection{House churches}

Houses and Households constitute not only the receptive settings for the communication of the good news in Luke-Acts. Households also represent, according to Luke, the basic social organization, house-churches, through which the gospel made its advance from Palestine to Rome. The church spread from olkos to oixos (Ac 20:20): from the Households of Galilee, Jerusalem and Jericho to those of Damascus (Ac 9:10-19), Joppa (9:43; 10:6, 17-18, 32), Caesarea (10:1-11:18; 21:8), Tyre (21:3-6), Philippi (16:15, 34, 40), Thessalonica (17:5-7), Ephesus (20:20), Troas (20:7-12), Corinth (18:3, 7-8) and Rome (28:16, 23, 30-31). The hospitality, fellowship, and mutual support typical of these house church communities united itinerant prophets and residential believers in a cooperative effort which, for Luke, was essential to the success of the Church's missionary enterprise (Koenig 1985:85123).

\subsection{Domestic life in the teaching of Jesus}

Scenes of domestic life likewise play a major role in the Lucan presentation of the teaching of Jesus. Of the thirty-one parables which Luke relates, no less than eighteen involve aspects of domestic activity and Household management (olkovopía): 8:5-8; 12:35-40; 12:42-46; 13:18-19; 14:15-24; 15:3-7; 20:9-18; and unique to Luke: $7: 41-43 ; 11: 5-8 ; 12: 16-21 ; 13: 24-30 ; 14: 7-11 ; 14: 28-30 ; 15: 8-10$; $15: 11-32 ; 16: 1-8 ; 16: 19-31 ; 17: 7-10$. Familial relations, domestic crises and responsibilities of Household management serve here as in briefer sayings of Jesus 
(9:46-48; 11:14-23; 12:22-34, 35-48; 13:20-21; 18:15-17) as Luke's preferred basis for illuminating major features of life in the kingdom of God. Children of the Household are contrasted to Temple and Torah authorities to exemplify humility, dependence on God, and discipleship (Kodell 1987). To hear the words of Jesus and do them is compared by Luke, as by Matthew, to building one's house on a firm foundation (Lk 6:46-49/Mt 7:24-27).

\subsection{Household blocks of teaching}

At points in the Lucan composition, moreover, blocks of teaching concerning discipleship appear organized around related Household concerns: 12:1-53 (1-3, no Household secrets; 4-12, no anxiety over survival; 13-21, 22-31, 32-34, inheritance, covetousness, possessions, almsgiving, trust in a divine Father's care; 35-40, Household vigilance; 41-48, domestic steward's faithfulness; 49-53, divisions in the Household); 14:1-17:10 (14:1-6, 7-11, 12-14, 15-24, dining, healing, inclusive hospitality; 14:25-35, renunciation of all, including family, to follow Jesus; 15:1-32, eating with and embracing the 'lost'; 16:1-9, 10-12, prudent and faithful Household management; 16:13, 14-15, Household loyalties and priorities; 16:16-17, Household [kingdom] entrance; 16:18, marital unity; 16:19-31, domestic inhospitality and unrepentance; $17: 1-4,5-6$, offense to children ['little ones'], forgiveness of brothers, faith; 17:7-10, the duty and status of Household servants).

\subsection{Household as symbol of the kingdom of God}

Throughout all this teaching of the Lucan Jesus, the oikos serves as the most apposite sphere and symbol of social life for illustrating features of life under the reign of God. In this connection the institution of kinship and family based on consanguinity and affinity provides a model for a community of fictive kin united by the bonds of mercy, faith and filial obedience. The boundaries of this symbolical family or Household of God are expanded to include the marginated, the outcasts, Samaritans, and Gentiles.

In this kingdom/Household, God is experienced as a merciful, generous, and forgiving 'father' (Lk 2:49; 6:36; 9:36; 10:21-22; 11:1, 13; 12:30, 32; 33:29, 42; 23:34, 46; 24:49; Ac 1:4, 7; 2:33). Jesus is recognized as 'Son of God' (Lk 1:35; 3:22; 4:3, 9, $41 ; 8: 28 ; 9: 35 ; 10: 22 ; 20: 13 ; 22: 70$; Ac 8:37; 9:20; 13:53). Believers who hear and do Jesus' words in contrast to the 'children of Jerusalem' (13:34) form his new family (8:19-21) and become the true 'children' of the heavenly Father $(11: 13 ; 24: 49)$, 'brothers and sisters', one with another (Lk 6:41-42; 8:19-21; 17:3-4; 22:32; Ac 1:15, $16 ; 2: 29,37 ; 6: 3 ; 9: 17,30 ; 10: 23 ; 11: 1,12,29 ; 12: 17 ; 14: 2 ; 15: 1,3,7,12,22,23,32,33$, $36,40 ; 16: 2,40 ; 17: 6,10,14 ; 18: 18,27 ; 21: 7,17,20,22 ; 22: 13 ; 28: 14,15)$. In this 
kingdom/oikos Jesus is the generous lord and 'Householder' (oikooforótns) (12: $35-40 ; 12: 22-30 ; 14: 7-11,12-14,15-24 ; 19: 11-27)$ and the meals of which he speaks $(14: 7-24 ; 15: 3-32)$, over which he presides $(22: 7-38 ; 24: 28-31,36-49)$ and at which he serves $(12: 37 ; 22: 27)$ are signs of the inclusiveness, fellowship, status reversal, reciprocal service, and joy typical of life in the kingdom/oikos of God. Those who share in the fellowship of this Household are those who hear the Householder's words and do them, 'Household stewards' (oikovó $\mu$ os, 12:42; 16:1-9) and 'servants' (oikétns, 16:13) responsible for the things entrusted to them. Their master's humble service in the olkos is the model for their own (17:7-10; 22:24-27). In the oikos of God they are united with their Lord and one another in new, inclusive bonds of kinship (8:19-21), generosity, and friendship (11:5-13; 12:4; 14:7-11, 12-14; 16:9). As Jesus was 'the friend of tax collectors and sinners' (7:34; cf 7:36-50;15:2; 19:1-10), the friendship of his followers likewise, as Acts makes clear (10:24; 19:31; 27:3), knew no social or ethnic limits.

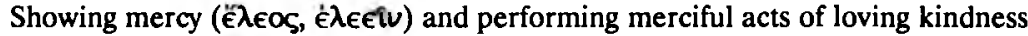

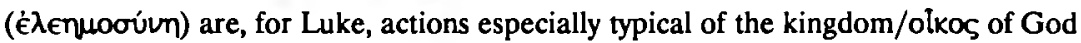
(12:33). The Lucan gospel begins with rejoicing over the divine mercy linked with Jesus (1:76-79) and manifested to lowly women, Mary (1:50,54) and Elizabeth (1:58) as representatives of expectant Israel. Mercy, moreover, is exercised concretely in the healing of sinners and the unclean: lepers (17:11-19); a blind man (18:35-43); one near death (10:29-37); a lame man (Ac 3:1-10). Works of mercy, beyond the mere gift of alms, involve deeds of loving kindness: hospitality, the rearing of orphans, assistance at weddings, redemption of prisoners, care for the sick, burial of the dead, comfort of mourners (Strack-Billerbeck 1961:536-610) actions noted by Luke as typical of Jesus and his community. This mercy knows no limits set by purity regulations but is available to and practiced by all who do the father's will (10:25-37; 11:37-41; 17:11-19; 18:35-43; Ac 3:1-10; 9:36-43; 10:2, 4, 31; 24:17). To love one's enemies, do good, lend with no expectation of return is to be a

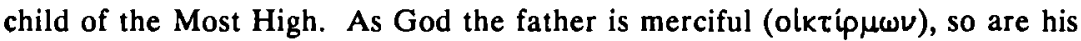
children to be merciful (6:35-36).

\subsection{The Household institution in Luke-Acts: A summary}

In Luke-Acts the Household plays a paramount role in the ministry, teaching, and mission of Jesus and his followers. Historically and geographically, Households of believers mark the way-stations of the spread of the gospel from Galilee to Rome. Economically and socially, they constituted independent, self-subsistent communities organized on the basis of kinship and Household management. Politically, they played no part in Palestine's power structure except as the supplier of its economic 
resources and the object of its devouring policies. Here among the Households of the holy and the unholy, the wealthy and the poor, Jews and Gentiles of high and low degree, the good news of a holiness and wholeness available to all made its initial and sustained advance. Household organization was determined by the structure and roles of the family and regulated by the traditional customs and codes of family life and kinship relations. These domestic structures and codes, in turn, supplied Jesus and his company with the basic models and metaphors for illustrating the relations and conditions of life in the kingdom of God. Biological kinship and its attendant roles, relations, and responsibilities served as the model for conceptualizing relations with God as father and fellow believers as brothers and sisters in the family of God. Qualities of both the honorable human father and the divine parent - generosity, mercy, hospitality, loyalty, friendship - were those qualities to be emulated by the family as a whole.

The Household thus serves in Luke-Acts as both a historical and a metaphorical reality. The church which grows through Household conversions becomes at the same time a worldwide Household of faith. The contrast to the Temple as historical institution and erstwhile sacred symbol is clear: political institution versus kinship institution; centralization of power and coercion versus diffusion of the powerless Households and familial commitment; economic exploitation versus material sharing; stratification by purity versus integration via kinship and fictive kinship bonds; exclusion and alienation based on purity lines versus inclusion based on mercy and faith. The former, for Luke, is the object of critique and the arena of rejection, Satan-inspired conflict and death. The latter is object of praise and the sphere of repentance, concord and divinely conferred life. Thus, in Luke's account, the Spirit of God and its sanctifying power moves from Temple to Household, from the chief symbol of Jewish national identity to the principal symbol of a community united with a heavenly Father. In Luke-Acts the Household emerges as the preeminent sphere and symbol of the reception of the gospel, Christian identity, and solidarity in the Spirit.

\section{TEMPLE AND HOUSEHOLD CONTRASTED IN LUKE-ACTS}

This concludes our examination of the two major institutions in Luke-Acts, the Temple and the Household. The evidence indeed supports the thesis that throughout Luke-Acts, as in Luke 18:9-14 in particular, Temple and olkos represent distinctly different and contrasted types of social institutions with conflicting sets of structures, interests, values, beliefs and behaviors. The following table summarizes the salient contrasts. 
TABLE 1

TEMPLE

HOUSEHOLD

* SPACE

National sanctuary located in Jerusalem, the Holy City;

One single Temple;

Spatial demarcation of degrees of holiness;

Central locus and symbol of political power;

- PERSONNEL

Chief priests and families; priests, Levites; money-changers; Temple police; Sanhedrin (chief priests scribes, elders); Pharisees and Saducees;

* POLITICAl RELATIONS

Central base of political, economic, social and cultural (religious) power;

Temple and administration under direct Roman control;

Bureaucratic authority (offices and qualifications);

\section{- ECONOMIC RELATIONS}

Treasury, Temple tax, sacrifices, offerings, tithes to priests;

Accumulation of debts;

Expropriation of property, 'greed', 'den of thieves';

Oppression of the poor and powerless; Redistribution of resources according to interests of wielders of power;
Communal profane space located in villages and cities;

Many Households;

Spatial demarcation of degrees of intimacy;

Diffused, distant from center of political power.

Families, fictive kin; Householders, stewards, servants; friends; neighbors; guests.

Periphery, no public power; base of kinship;

Indirect Roman control;

Traditional authority, ascribed roles and statuses.

Reciprocal generosity, property in common;

Forgiveness of debts;

Sharing of property;

Care for poor and powerless;

Sharing of resources according to availability and need. 
* SOCIAL RELATIONS

Stratified society according to degrees of purity (Torah);

Rank according to bureaucratic roles;

Exclusive space and society according to purity (Torah), zone of alienation and self-justification;

Sphere of unrepentance, conflict, death plotting;

Temple system object of Jesus' critique;
Solidary kin and fictive kin group ('brothers and sisters, children of God' by faith and mercy);

Rank according to traditional familial roles;

Inclusive groups according to faith and mercy, zone of integration and divine justification;

Sphere of acceptance, repentance, concord, life;

Domestic relations object of Jesus's teaching and praise.

The dwelling-place of the Spirit, sphere of God's activity; Chief social symbol of the kingdom of God and Christian holiness.

* SYMBOLIC FEATURES

Perversion of God's dwelling-place, sphere of Satan's activity;

Chief public symbol of Jewish identity and purity;

\section{TEMPLE, HOUSEHOLD AND CONTRASTING SETS OF SOCIAL RELATIONS}

Thus far it has become clear that in Luke-Acts Temple and Household symbolize different and opposed forms of social organization, identity and allegiance. Now it is appropriate to inquire as to the reason for this particular choice of symbols. It goes without saying, of course, that both the Temple and the Household played major roles in the actual history of Jesus and the Jesus movement. Neither are fictions of Luke's narrative world. But what explains their particular elaboration, accentuation and contrast in Luke's narrative? Why are Temple and Household poles around which Luke has woven his story? How does Luke's depiction and contrast of Temple and Household institutions resonate with the societal structures familiar to his audience? Why did Luke have reason to expect that a contrast of these two institutions and the social relations they involve would strike his hearers/readers as plausible and persuasive? Recent studies by Halvor Moxnes and Bruce Malina describe a useful social-scientific model for pursuing these questions.

The significance of particular institutions and groups in Luke-Acts and their function in the narrative, Moxnes $(1987,1988)$ notes, can best be determined by 
examining them in relation to the social relations typical of the society within which and for which Luke writes. Underlying the economic and social modes of interaction and conflict described in Luke-Acts, he demonstrates (following the work of Marshall Sahlins $(1965,1972)$ were broader contrasting patterns of relations based on ancient systems of either reciprocity or redistribution. As reciprocal (direct, person-to-person give-and-take) forms of interaction were characteristic of the Household and local village life in first century Palestine, so centralized accumulation of agricultural surplus and redistribution were typical of the general Temple-based economy.

These contrasting modes of social exchange, according to Moxnes, played a key role in shaping social dimensions of the conflict between the Jesus movement and the Temple establishment as described in Luke-Acts. Before considering this role in more detail, however, let us first examine the analytical model and its operative terms, as more extensively clarified by Malina.

\subsection{A comparative model of ancient social relations}

In his pioneering study, Christian origins and cultural anthropology, Bruce Malina (1986:98-111) proposed a schema for analyzing differing forms of social relations and interactions characteristic of the societies and groups described in the biblical writings. This schema coordinates research of social and economic anthropologists on primitive and peasant societies analogous to those of the biblical period (Sahlins 1965, 1972; Carney 1975:137-234; Sack 1986:52-91).

Forms of social'relations (including economic exchanges) in pre-industrial societies, Malina notes, fall along a spectrum marked by types of reciprocity at one pole of the spectrum to types of redistribution or centricity at the other. Reciprocal relations, involving personal, back-and-forth exchanges of goods and services, are typical of small-scale societies, tribal organizations, village and household life. At this level of direct, personal and local interaction, food, clothing, shelter, hospitality and other basic necessities of social life are either (a) shared freely according to generosity or need (generalized reciprocity), (b) exchanged symmetrically according to the interests of both parties (balanced reciprocity), or (c) obtained with no concern for the other's self-interest (negative reciprocity). The types of reciprocity will vary according to prevailing social conditions; the proximity (personal and geographical) of the agents, and the purpose, mode, place and time of the interactions. Households, kin and fictive kin groups regularly practice generalized reciprocity among themselves, evidencing the closeness of social bonds and the concern for freely-given mutual support. Balanced and negative forms of exchange are typical where social ties and trust between groups are weaker and interactions 
are more infrequent.

Forms of redistribution, on the other hand, are typical of large-scale societies with central storehouse economies such as the temple-based societies of Mesopotamia, Egypt, Palestine and Rome (Carney 1975:172-175). While these political economies include reciprocal forms of exchange on local levels, their differentiating feature is the pooling of goods and services in a central storehouse, generally linked to a temple, and their centralized political control and redistribution by a powerful elite or temple hierarchy. In this form of social organization, based on the political rather than the kinship institution, the management of the entire collectivity is of paramount concern and redistribution occurs according to the interests of those in power. "Centricity with its pooling and redistribution generates the perception of social unity...replicates the social structure with its rank order, and presupposes centralized organization of social order and social action' (Malina 1986:110). Economic and social relations are asymmetric and stratified according to norms favoring the elites. In place of the consensus and commitment typical of kinship-based reciprocal relations, submission and allegiance are marshalled through a consolidation of political, legal and military power, enforcement of social stratification and boundaries, and control of the cultural (including religious) tradition (see Sack 1986:61, 68, 71 for diagrammatic summaries of reciprocity and redistribution patterns, and Scott 1977 for their relevance to the issue of justice in particular). Contrasting features of these orderings of social and economic relations are summarized in the following table.

\section{TABLE 2 : CONTRASTS IN REDISTRIBUTION AND RECIPROCITY}

\section{REDISTRIBUTION}

\section{GENERALIZED RECIPROCITY}

\section{* SCALE}

Large-scale national populations;

\section{- POLITICAL RELATIONS}

Centralized political, economic, social and ideological control;

Coerced pooling of agricultural surplus, corvee, imposition of debts, taxes, tithes, redistribution according to interests of elites;
Small-scale village populations, urban groups.

Power sharing, consensus;

Voluntary, back-and-forth sharing of 'gifts': food, shelter, clothing, tools, etc, giving without expectation of immediate return; 
Central store-house economy with temple depot;

Centralized control of production, distribution, consumption of resources and services;

Redistribution of available surplus according to interests of power wielders;

Economic and social imbalance of 'haves/have-nots', elites and subelites according to control of resources, means and relations of production;

- SOCIAL RELATIONS

Indirect interaction of classes through mediating agencies, maintenance of allegiance to system through socialization and norm enforcement;

Social roles and status according to political and economic power, proximity/distance from power center, law, military;

* CUltural TRADition

Centralized control of cultural tradition, ideology shaped by interests of elites and temple hierarchies;

* LIMITATIONS

Centralization prone to agglomeration of power and resources, totalitarianism, land expropriation;
Diffused, local 'household management';

Household control of production etc;

Reciprocal exchange of goods and services according to their availability and need;

Balanced relations through mutual sharing of goods at common disposal.

Direct, face-to-face interaction of agents, fidelity in obligations as a matter of familial loyalty and group honor;

Traditional domestic roles and status, honor and prestige according to exercise of generosity and commitment to traditional norms of mutual sharing.

Cultural tradition shared through domestic networks in interest of kin and fictive kin solidarity.

Reciprocal relations constrained by absence of centralized authority and group pressure; 
Redistribution inadequate in times of crisis (crop failure, plagues) resulting in sub-subsistence conditions, banditry and at times revolt;
Obligations of reciprocity especially stressed in crises involving personal survival.

This model summarizes and compares differing forms of social organization and interaction typical of pre-industrial societies including those of Jesus' and Luke's time. In particular it clarifies in general, abstract terms differences in the ways that small-scale, kinship based groups and large-scale, national populations with a centralized political base were socially organized to manage the exchange of goods and services and all forms of social interchange. For our purposes the model is useful in three important ways. First, it provides a schema for conceptualizing differing forms of social organization prevalent in the Mediterranean world of the first century and known to Luke and his audience. This was a world rife with competing systems of redistribution (Palestine, local monarchies, Rome) and reciprocity (families, villages, urban enclaves). Secondly, the contrasting features of redistribution and reciprocity arrangements which the model makes evident provide categories for organizing and analyzing Luke's description and assessment of economic-social conditions. This in turn will help clarify implications of the choice of Temple and Household as contrasting foci of the Lucan narrative. Finally, the fit between the social arrangements of Luke's world and the material and accents of his composition will allow us then to assess the plausibility and persuasive power of Luke's story concerning Temple and Household for his contemporary audience.

\subsection{The model applied to Luke-Acts}

The social arrangements typical of Luke's world echo in the material and patterns of his two-volume work. When this model of contrasting forms of social relations is used as a lens through which to analyze the social data of Luke-Acts, it becomes apparent that in his contrast of Temple and Household Luke is describing and evaluating two different types of social organization known to his audience. In the language of our model, the one is a centralized, politically controlled redistributive system with the Jerusalem Temple as its center, and the other, a movement organized around Households and kin/fictive kin relations which is united by bonds and obligations of generalized reciprocity.

The Jerusalem Temple as the base of first century Palestine's redistribution economy and the destabilizing impact of the management of this system in all areas of Palestinian life has been described by Oakman (1986:37-91) and others (Hamilton 1964; Brown 1976; Fenelly 1978; Houtart 1980:218-260; Belo 1981: 60-86; Fussel 
1987:29-50). This system, controlled politically by an alliance of large landholders (chief priestly families, lay elders, Herodians) in collaboration with Rome's colonialist policy, through an excessive burden of tribute, Temple taxes and offerings, tithes and other debts, was seriously altering ancient land-holding patterns and eroding traditional forms of social relations. An ever-increasing amount of the peasant population, incapable of meeting the enormous exactions imposed by Rome and the Temple, was being forced to sell its lands and its family members into debt slavery. Impoverishment of the masses, imprisonment, destitution and social unrest was on the rise. The gap between the landed 'haves' and the landless 'have nots' was growing, village patterns of cooperative labor and reciprocal social relations were being destroyed, and the poor and the powerless, once protected by the norms of Torah, were now the objects of exploitation and abandonment.

From Luke's perspective, as we have seen above, this was a system which had grown morally bankrupt. The Temple, once a holy house of prayer had become a den of thieves (Lk 19:46). The guardians of Temple law, purity and power, preoccupied with status and class differentiation (Lk 11:43, 54; 15:2; 16:15; 18:11), had imposed heavy burdens ( $L k$ 11:46), ignored the needy (Lk 10:29-37), neglected justice and the love of God (Lk 11:42), were full of extortion and wickedness (Lk 11:39) and devoured widow's houses ( $L k$ 20:47). Their interpretation of Torah and the cultural tradition was oppressive and self-serving (Lk 11:37-52; 16:14-15; 18:11-12; 20:9-19). Their response to criticism was violent and murderous (Lk 11:53-54; 19:47; 20:19; $21: 12 ; 22: 2 ; 22: 47-23: 5 ;$ Ac 3:13-15; 4:1-3 etc). The entire system and iț chief symbol, the Temple, because it had failed in the distribution of not only material resources but also justice, mercy and peace, was destined by God for destruction (Lk 11:34-35; $19: 41-44 ; 21: 5-6,20-24)$.

In contrast to this bankrupt system of the Temple, on the other hand, according to Luke, was an organization of communal life marked by the reciprocities of kinship, friendship and domestic relations. As our model makes clear, the features of domestic life which Luke has accented are relations characterized by forms of generalized reciprocity.

Within the Christian network of Households and the community of 'brothers and sisters in the faith', social relations were intimate, inclusive and governed by the reciprocity characteristic of family and friends. In this private sphere, social (including religious) life was self-contained and economically self-supporting. Resources were not directed under compulsion to a distant center and redistributed according to the interests of those in power, but were shared directly according to availability and need (Lk 6:3-36; 11:5-13; 12:33; 15:3-32; 18:22; 19:1-10; Ac 2:44-47; 5:32-37; 6:1-6). No holy place or hierarchy set standards for social differentiation because in the 
brotherhood of the fàithful all was holy (Lk 11:4-41; Ac 10-11:18; 15:9); all persons were equally servants (Lk 17:7-10; 22:24-27). Humility (Lk 14:7-11; 18:14) rather than elitism, inclusivity (Lk 14:12-24; Ac 10:1-11:18) rather than exclusivity, consensus (Ac 2:42; 4:32) rather than constraint, personal commitment (Ac 3:11-16, 4:8-12, 5:2331) rather than abstract allegiance was the rule here, as typical of reciprocal relations. The private space of house and home was the scene where hospitality, generosity, friendship, deeds of mercy, acts of mutual aid and comfort, familial love and fraternal support, unmeasured and unlimited, welded bonds of intimacy and solidarity. Here the honorable person was the generous one who had given all away (and so was wealthy beyond measure in social prestige and honor before God; of Luke 12:33-34; 18:22; 21:1-4). Here in relations marked by reciprocity, giving (Lk 14:12-24) and forgiving (Lk 7:37-50; 11:4; 15:1-32; 19:1-10) were never once-for-all but on-going activities which bound partners in an open-ended and continuous relationship.

These contrasts in the structures, norms and values associated with redistributive or reciprocal forms of social relations represented by Temple and Household make clear how and why the Household rather than the Temple served Luke as the most apposite image for concretising the good news of the kingdom and the social features of a Christian community faithful to a God of mercy and justice. The ethos of the kingdom, according to Luke, is shaped by the logic of generalized reciprocity typical of the Household and the bonds and obligations of kin and fictive kinship. Given the economic and social cleavages within the missionary communities addressed in LukeActs (Karris 1979; Esler 1987:164-200), it was precisely this ethos of sharing which was essential for the continued viability, solidarity and growth of the fledgling movement.

Luke's interest in the reciprocities of the Household is especially evident in his stress on giving/forgiving/lending without expectation of return (Lk 6:30, 35 [cf 3234]; 7:41-42; 10:29-37; 11:4; 14:12-14, 15-24; Ac 20:35) other than a future heavenly reward (Lk 6:37-38; 12:32-34; 14:12-14, 15-24; 18:22). This benevolence (mercy/ alms) is intended especially for 'the poor, the maimed, the lame, the blind' (Lk 14:13), those lost and lowly ones (Lk 19:10), social deviants and ethnic outsiders (Samaritians, Gentiles) to whom the gospel of Jesus was particularly directed (Lk $4: 16-30 ; 12: 33 ; 18: 22 ; 19: 8-9$ ). Such deeds of mercy and justice/ righteousness (Karris 1985:23-78) are explicitly identified as the true purity (11:41) which unites benefactors with both beneficiaries and their benefactor God (6:35-36; 12:29-34) and Lord (Ac 10:38). Thus mercy rather than cultic purity is the essential bond between the people of God and their heavenly Father (Lk 6:36; cf Borg 1984:73-195).

This benevolence, exemplified by the centurion at Capharnaum (Lk 7:1-10), the good Samaritan (10:29-37), Zacchaeus (19:1-10), Barnabas (Ac 4:36-37) and 
Cornelius (Ac 10:2), typifies the mutual sharing of the Christian community in general (Ac 2:43-47; 4:32-37) as it embodies the generosity of its divine Benefactor (Danker 1987, 1988) and thereby establishes its honor in a benefaction-conscious society (Danker 1982).

Giving without expectation of return, hospitality and the sharing of food and shelter, care for the ill, generous support of those in need, forgiveness of debts and redemption of those in debt are all actions characteristic of kin groups and the ethos of the Household. In Luke-Acts this pattern of domestic relations and the intimacy and solidarity it presumes, serves as the decisive model for the identity and ethos of the Christian community as a whole. This form of community organized around the roles, relationships and responsibilities of the Household stands in stark contrast to the exploitative system of the Temple and embodies an alternate vision of salvation based not on cultic purity but on the gift of divine mercy and its imitation in the family of faith.

Luke's portrait of Temple and Household is just that: a portrait whose highlights and hues are conformed to the artist-author's perspective and the contours of his work as a whole. This portrait, however, will have been plausible and persuasive to his contemporary audience because it presumed and conformed with facts of social and economic life known from personal experience. Though by the time of Luke's writing the Jerusalem Temple lay in ruins for decades or more, his audience was well acquainted with the opposing types of social organization represented by a Temple state on the one hand and a network of Households on the other. This audience could hardly miss the implications of Luke's pointed contrast between a Holy Place which had become an exploitative den of thieves and a widespread community of brothers and sisters who in faith and deeds of loving kindness shared all things in common.

\section{CONCLUSION}

Temple and Household and the contrasting realities which they embody assume a fundamental significance in Luke-Acts, both structurally and thematically. As the Temple frames and provides the central focus for the first segment of Luke's narrative, the Household frames and marks the chief focus of the second part of the narrative. In the structure of Luke-Acts, this shift in focus embraces and replicates a major plot device pervading the entire narrative. At the same time, this transition in venue and focus from Temple to Household charts for Luke the actual historical and geographical movement of the gospel from its inception in the Holy Land, the Holy City and the Holy Place to its dissemination through the Households of the Diaspora, 
'from Jerusalem, Judaea and Samaria to the end of the earth' (Ac 1:8).

Thematicaly, Temple and Household are likewise linked with basic Lucan emphases and contrasts. The social and economic system centered in Temple, Torah and purity where just redistribution had failed served Luke as a negative foil with which to compare the social and economic relations of the Household as the arena of justice, mercy and kotvwvio and sphere of the Spirit's presence. Over against a system dominated by a central holy place, an exclusivist holiness ideology, a hierarchically stratified social order and exploitative economic interests, a system incapable of mediating the inclusive salvation envisioned by the prophets, Luke contrasts the domestic associations of the movement initiated by Jesus. Here the gospel of a universal salvation is socially embodied in a community of 'brothers and sisters' where repentance, faith, forgiveness, generosity, mercy and justice, familial loyalty and friendship unite the faithful with a God of mercy and a Servant-Lord.

Household scenarios and domestic imagery serve the unfolding of distinctively Lucan christological, soteriological and ecclesiological themes: Jesus Christ as exalted Servant and Benefactor; salvation for the lost and the lowly, women and outcasts, Gentiles and sinners; repentance and forgiveness; almsgiving and mercy; hospitality and table-fellowship. The Household, in fact, functions as Luke's prime metaphor for depicting social life in the kingdom of God.

The themes of promise and fulfillment and Christianity's continuity with Israel likewise are linked with Temple and Household. For Luke the hope of Israel's salvation, initially linked with the Temple, is finally realized in the reciprocities of the oikos. The role of the Temple has been superceded and there is no reason for regret over its destruction. His critique, however, is specific, not general. It is directed not against the Jews as a people but against a bankrupt political system of Temple-Torahpurity in particular. In his economy of salvation, the new Household of Jesus Messiah, not the Temple, constitutes the continuing dwelling place of the Spirit, Christianity's enduring bond with the house of Abraham in whose posterity 'all the families of the earth will be blessed'.

The contrast and developing conflict of Temple-based and Household-based communities also epitomizes historically, geographically, socially and ideologically Luke's view of the cleavage between the worlds and allegiances of Judaism and Christianity. It is the latter, he maintains, which alone constitutes the fulfillment of the prophetic hopes and the divine promise of a universal salvation offered by a God of mercy who in Jesus Christ has made all things clean and all persons children of one universal family.

Returning to where we began, we can conclude that the 'dominant contradiction' between alienated and human space which Mottu saw expressed in the Temple/ 
otkos contrast of Luke 18:9-14 is part of a larger Lucan pattern in which the Temple and the Household point to contradictory definitions of social and religious life. Our comparative model of social relations has enabled us to see that this contradiction involves not simply differing locales but differing structures of economic and social organization, opposing forms of social relations, alternative sets of values and loyalties, and contrasting symbols of social and religious identity. By identifying the salient areas of contrast between these two dominant institutions, the model explicates features of Temple and Household which are presumed but implicit in the predominantly theological narrative of Luke-Acts.

In Luke's predominantly theological vocabulary, the Temple was a house of prayer and hope perverted into a den of thieves, the dominant symbol of a holiness ethic opposed to the inclusive holiness of God. The Household, in turn, was the zone of the Spirit and the home of the children of God, the prime metaphor of life in the kingdom. Translated into social terms, the Temple, its authorities, its law, and its controlling purity ideology represented, from Luke's perspective, an exclusivist, exploitative, and alienating system incapable of providing access to or symbolizing the ultimate sources of personal and communal sustenance. It opposed but failed to contain a reforming movement seeking justice and support for the powerless and intent on extending the boundaries of Israel to include all seeking a place of belonging, acceptance, and succour. This movement, shaped in its ethos and ethic by the reciprocities of kinship and friendship, and united by a sense of common brotherhood/sisterhood under one divine Father, freed itself from the restraints of Temple purity, allegiance, and national boundaries as it embraced 'all the families of the earth' in its worldwide mission.

\section{Works cited}

Bachmann, M 1980. Jerusalem und der Tempel. Die geographisch-theologischen Elemente in der lukanischen Sicht des jüdischen Kultzentrums. Stuttgart: Kohlhammer. (BWANT 109.)

Baltzer, $\mathrm{K}$ 1965. The meaning of the Temple in the Lukan writings. HThR 58, 263277.

Belo, F 1981. A materialist reading of the Gospel of Mark. Maryknoll: Orbis.

Borg, M J 1984. Conflict, holiness and politics in the teaching of Jesus. Lewisten: The Edwin Mellen Press. (Studies in the Bible and early Christianity 5.)

Carney, T F 1975. The shape of the past: Models and antiquity. Lawrence: Coronado. Casalengo, A 1984. Gesu e il tempio: Studio redazionale di Luca-Atti. Brescia: Morcelliana. 
Cassidy, R J \& Scharper, P J (eds) 1983. Political issues in Luke-Acts. Maryknoll: Orbis.

Danker, F W 1982. Benefactor: Epigraphic study of a Graeco-Roman and New Testament semantic field. St Louis: Clayton.

--- 1988. Jesus and the new age: A commentary on St Luke's gospel. 2nd revised and expanded edition. Philadelphia: Fortress.

-- 1987. Luke: Proclamation commentaries. 2nd revised edition. Philadelphia: Fortress.

Elliott, J H 1981. A home for the homeless: A sociological exegesis of 1 Peter, its situation and strategy. Philadelphia: Fortress.

Esler, P F 1987. Community and gospel in Luke-Acts: The social and political motivations of Lucan theology. New York: Cambridge University Press. (SNTS MS 57.)

Fennelly, J M 1983. The Jerusalem community and Kashrut Shatnes, in Richards, K H (ed), Society of Biblical Literature seminar papers, 273-288. Chico: Scholars Press.

Hamilton, N Q 1964. Temple cleansing and Temple bank. JBL 83, 365-372.

Houtart, F 1980. Religion et modes de production précapitalistes. Brussels: Université de Bruxelles.

Jeremias, J 1969. Jerusalem in the time of Jesus. Philadelphia: Fortress.

Karris, R J 1985. Luke: Artist and theologian. New York: Paulist Press.

Kodell, J 1987. Luke and the children: The beginning and end of the great interpolation (Lk 9:46-56, 18:9-23). CBQ 49, 415-430.

Koenig, J 1985. New Testament hospitality: Partnership with strangers as promise and mission. Philadelphia: Fortress.

Malina, B J 1981. The New Testament world: Insights from cultural anthropology. Atlanta: John Knox.

--- 1986a. Christian origins and cultural anthropology: Practical models for biblical interpretation. Atlanta: John Knox.

--- 1986b. Religion in the world of Paul: A preliminary sketch. BTB 16, 92-101.

Mottu, H 1974. The Pharisee and the tax collector: Sartian notions as applied to the reading of Scripture. USQR 29, 195-213.

Moxnes, $\mathbf{H}$ 1986. Meals and the new community in Luke. SEA 51/52, 158-167.

-.- 1987. The economy in the Gospel of Luke in light of social anthropology, in Moxnes, $\mathrm{H}$ (ed), Economy in the New Testament, 1-35. (Urkristendommen: Prosjektshefte 2.)

..- 1988. The economy of the Kingdom: Social conflict and economic interaction in Luke's gospel. Philadelphia: Fortress. 
Neusner, J 1973. The idea of purity in ancient Judaism. Leiden: Brill.

Neyrey, J H 1984. 'They turn the world upside down.' The idea of purity in LukeActs: Insights from cultural anthropology. Paper presented at the Annual Meeting of the Catholic Biblical Association of America.

--- 1986. The idea of purity in Mark's gospel, in Elliott, J H (ed), Social-scientific criticism of the New Testament and its social world. Decatur: Scholars Press. (Semeia 35, 91-128.)

Nida, E A 1975. Componential analysis of meaning: An introduction to semantic structures. The Hague: Mouton. (Approaches to Semiotics 57.)

Oakman, D E 1986. Jesus and the economic questions of his day. Lewiston: Edwin Mellen. (Studies in the Bible and early Christianity 8.)

Richard, E 1983. Luke - writer, theologian, historian: Research and orientation of the 1970's. BTB 13, 3-15.

Sack, R D 1986. Human territoriality, its theory and history. New York: Cambridge University Press. (Cambridge Studies in Historical Geography 7.)

Sahlins, M D 1965. On the sociology of primitive exchange, in Banton, M (ed), The relevance of models for social anthropology. London: Tavistock. (Association of Social Anthropologists Monographs 1.)

-.- 1972. Stone age economics. Chicago: Aldine Press.

Scott, J C 1977. The moral economy of the peasant: Rebellion subsistence in Southeast Asia. New Haven: Yale University Press.

Tannehill, R C 1986. The narrative unity of Luke-Acts: A literary interpretation, Vol 1. Philadelphia: Fortress.

Weinert, F D 1981. The meaning of the Temple in Luke-Acts. BTB 11, 85-89.

--- 1982. Luke, the Temple and Jesus' saying about Jerusalem's abandoned house. $C B Q$ 44, 68-76. 